\title{
Tingkat Pengetahuan Petani Padi Sawah (Oryza sativa L.) Terhadap Pertanian Organik di Desa Manunggal Jaya Kecamatan Tenggarong Seberang
}

\author{
Dina Lesmana ${ }^{1}$, Margareta $^{2}$ \\ 1,2Program Studi Agribisnis Fakultas Perrtanian Universitas Mulawarman, Samarinda, \\ Kalimantan Timur \\ 1Email : dinalesmana78@gmail.com
}

\begin{abstract}
Organic farming system is a system based on soil fertility as the key to the success of production by taking into account the natural ability of soil, plants and animal to produce good quality of agricultural and environmental products. The purpose of this study was to determine the knowledge level of lowland paddy farmers (Oryza sativa L.) to organic farming in Manunggal Jaya, Tenggarong Seberang. The research was conducted from May to July 2017. The sampling method used was purposive sampling with 37 respondens. The data collected in this research were primary data and secondary data. Methods of data collection was done by observation and direct interview with respondens. Data analysis using descriptive qualitative method. The result of this research indicate that knowledge level of lowland paddy farmers categorized as "high" in both beginner and advanced classes, but in the application phase of farmers was still difficult to apply. Then, for the beginner in the category of fertilization and control of pests categorized as "medium".
\end{abstract}

Keywords : Knowledge Level, Farmers, Lowland Paddy, Organic farming.

\begin{abstract}
ABSTRAK
Sistem pertanian organik merupakan suatu sistem yang berpijak pada kesuburan tanah sebagai kunci keberhasilan produksi dengan memperhatikan kemampuan alami dari tanah, tanaman, dan hewan untuk menghasilkan kualitas yang baik hasil pertanian dan lingkungan. Tujuan penelitian ini untuk mengetahui tingkat pengetahuan petani padi (Oryza sativa L.) sawah terhadap pertanian organik di Desa Manunggal Jaya Kecamatan Tenggarong Seberang. Penelitian ini dilaksanakan bulan Mei hingga Juli 2017. Metode pengambilan sampel yang digunakan adalah purposive sampling dengan jumlah responden sebanyak 37 orang. Data yang dikumpulkan dalam penelitian ini adalah data primer dan data sekunder. Metode pengambilan data dilakukan dengan cara observasi dan wawancara langsung dengan responden. Analisis data menggunakan metode deskriptif kualitatif. Hasil penelitian menunjukkan bahwa tingkat pengetahuan petani padi sawah terhadap pertanian organik di Desa Manunggal Jaya Kecamatan Tenggarong Seberang termasuk dalam kategori "tinggi", baik pada kelas pemula maupun pada kelas lanjut, namun dalam tahap penerapan petani masih sulit untuk menerapkannya. Kemudian untuk kelas pemula pada kategori pemupukan dan pengendalian OPT masuk dalam kategori "sedang".
\end{abstract}

Kata Kunci : Tingkat Pengetahuan, Petani, Padi Sawah, Pertanian organik

Pendahuluan

Pertanian organik dipandang sebagai jawaban dari kegagalan sistem pertanian konvensional, dimana sistem pertanian konvensional hanya mengutamakan kegiatan peningkatan produksi pertanian dengan menggunakan teknologi yang tidak ramah lingkungan sehingga dalam pelaksanaannya mengabaikan prinsip ekologi dan kearifan lokal. Berbeda halnya dengan pertanian organik yang dipandang sebagai suatu sistem pertanaman yang berasaskan daur ulang unsur hara secara hayati (Sutanto, 2002). 
Menurut Winarno (2004), pertanian organik merupakan suatu sistem pertanian yang didesain dan dikelola sedemikian rupa sehingga mampu menciptakan produktivitas yang berkelanjutan. Pertanian organik merupakan sistem pertanian yang berwawasan lingkungan dengan tujuan untuk melindungi keseimbangan ekosistem alam dengan meminimalkan penggunaan bahan-bahan sintetik dan merupakan praktek bertani alternatif secara alami yang dapat memberikan hasil yang optimal.

Prospek ekonomis dari pertanian organik cukup baik seiring dengan berubahnya pola konsumsi manusia, dimana manusia lebih memilih makanan yang sehat meskipun dengan harga yang lebih mahal (Soetrisno, 2002). Lebih lanjut, Prawoto (2002), menambahkan bahwa adanya perbaikan mutu kehidupan dan gaya hidup yang sehat untuk kembali ke alam. Gerakan ini didasari bahwa apa yang berasal dari alam adalah baik dan berguna, dan segala yang baik di alam selalu berada dalam keseimbangan.

Kalimantan Timur memiliki potensi yang sangat besar untuk mengembangkan pertanian sesuai Visi dan Misi Pemerintah Provinsi Kalimantan Timur yaitu melaksanakan revitalisasi pertanian dalam arti luas. Hal ini terbukti dengan keseriusan pemerintah dalam memprioritaskan bidang pertanian dalam rangka meningkatkan kesejahteraan petani dan masyarakat. Salah satu program yang diperkenalkan pada masyarakat tani di Kalimantan Timur adalah menuju pertanian berkelanjutan atau yang biasa disebut dengan sistem pertanian organik. Kabupaten Kutai Kartanegara merupakan salah satu Kabupaten di Provinsi Kalimantan Timur. Pemerintah Kabupaten Kutai Kartanegara telah berupaya dalam pengembangan kategori pertanian dalam arti luas untuk menunjang perekonomian daerah, khususnya mewujudkan pertanian organik dengan meninggalkan pola hidup lama yang menggunakan bahan kimia non alami, seperti pupuk, pestisida kimia, sintetis dan hormon tumbuh dalam produksi pertanian. Kecamatan Tenggarong Seberang merupakan salah satu kecamatan yang ada di Kabupaten Kutai Kartanegara yang turut ambil bagian dalam mengupayakan terwujudnya sistem pertanian menuju pertanian berkelanjutan melalui penerapan pertanian organik yaitu dengan melakukan kegiatan sosialisasi atau penyuluhan tentang pertanian organik yang dilakukan diberbagai desa yang ada di Kecamatan Tenggarong Seberang.

Desa Manunggal Jaya merupakan salah satu desa yang termasuk di wilayah Kecamatan Tenggarong Seberang yang sebagian besar penduduknya bermata pencaharian sebagai petani, komoditas pertanian yang dihasilkan antara lain padi sawah dan tanaman hortikultura. Sosialisasi dan penyuluhan telah diupayakan oleh pemerintah setempat untuk penerapan sistem pertanian organik, namun untuk menerapkannya tidak mudah dan memiliki banyak kendala. Paradigma masyarakat terhadap penerapan pertanian organik berbeda bahkan cenderung diabaikan, karena tingkat pengetahuan petani terhadap pertanian organik masih kurang. Selain itu, kuantitas hasil yang tidak 
signifikan pada saat-saat awal penerapan pertanian organik membuat beberapa petani enggan menerima pertanian organik, sedangkan pertanian modern dapat memberikan kuantitas hasil yang lebih cepat dan signifikan.

Berdasarkan uraian diatas dimana paradigma petani terhadap penerapan pertanian organik berbeda bahkan cenderung diabaikan, karena tingkat pengetahuan petani terhadap pertanian organik masih kurang. Tujuan penelitian mengangkat masalah bagaimana tingkat pengetahuan petani padi (Oryza sativa L.) sawah terhadap pertanian organik di Desa Manunggal Jaya Kecamatan Tenggarong Seberang.

\section{Metode Penelitian}

Penelitian ini dilaksanakan selama 3 bulan mulai dari Mei-Juli 2017 dengan lokasi penelitian di Desa Manunggal Jaya Kecamatan Tenggarong Seberang. Metode pengambilan sampel dilakukan secara sengaja (purposive sampling) yaitu petani yang pernah mendapatkan informasi tentang pertanian organik dari instansi pemerintah setempat. Jumlah petani yang pernah mendapatkan informasi tentang pertanian organik sebanyak 226 orang petani yang diambil dari jumlah anggota kelompok tani padi sawah yang pernah mendapatkan kegiatan penyuluhan pertanian organik yaitu Dewi Sri, Sido Maju, Tawang Sari, Sumber Rejeki, Tani Murni, Sumber Rejeki P, dan Pringgondani sehingga total keseluruhan jumlah populasi anggota kelompok tani 226 orang.

Salah satu cara untuk menentukan besarnya sampel dalam suatu penelitian agar mendapatkan yang representif adalah tingkat baku yang disesuaikan dengan tingkat kemampuan, tenaga, biaya, dan waktu tersedia, sehingga peneliti menetapkan untuk menggunakan nilai batas toleransi kesalahan 15\% dengan menggunakan rumus Slovin (Silalahi, 2015).

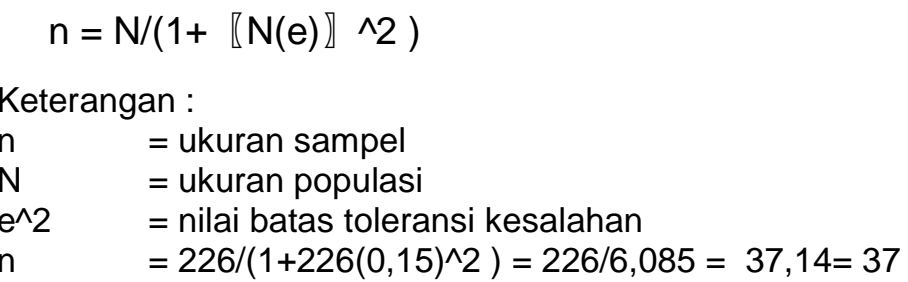

Berdasarkan perhitungan di atas telah didapatkan jumlah responden yang dapat mewakili keseluruhan dari jumlah populasi yaitu berjumlah 37 responden. Menurut Silalahi (2015), apabila sampel diambil dalam beberapa unit (kelompok), maka ditentukan jumlah sampel untuk tiap unit secara proporsional dengan formula sebagai berikut :

$$
\mathrm{ni}=\mathrm{Ni} / \mathrm{N} \times \mathrm{n}
$$

Keterangan:

ni = Jumlah sampel untuk menentukan stratum

$\mathrm{Ni} \quad=$ Jumlah populasi menurut stratum

$\mathrm{n} \quad=$ Jumlah sampel seluruhnya

$\mathrm{N} \quad=$ Jumlah populasi seluruhnya

Data Kelompok Tani di Desa Manunggal Jaya dapat dilihat pada tabel 1 : 
Tabel 1. Daftar Nama Kelompok Tani dan Jumlah Anggota Kelompok Tani

\begin{tabular}{llccc}
\hline No & Nama Kelompok Tani & Kelas & Jumlah Anggota & Jumlah Anggota \\
\hline 1. & Dewi Sri & Pemula & 31 & 5 \\
2. & Sido Maju & Pemula & 31 & 5 \\
3. & Tawang Sari & Pemula & 22 & 3 \\
4. & Sumber Rejeki & Lanjut & 22 & 4 \\
5. & Tani Murni & Lanjut & 30 & 5 \\
6. & Sumber Rejeki P & Lanjut & 47 & 8 \\
7. & Pringgondani & Lanjut & 41 & 7 \\
\hline & Jumlah & & $\mathbf{2 2 6}$ & $\mathbf{3 7}$ \\
\hline
\end{tabular}

Selanjutnya pengambilan sampel setiap unit dari ketua kelompok tani menentukan petani anggota kelompok untuk dijadikan sampel responden. Tingkat Pengetahuan Petani Padi Sawah Terhadap Pertanian Organik di Desa Manunggal Jaya diukur melalui indikator-indikator dengan masing-masing indikator menggunakan metode Likert. Indikator-indikator tersebut dianalisis lebih lanjut secara deskriptif kualitatif dengan mendeskripsikan masing-masing indikator menjadi beberapa item pertanyaan yang telah disusun dalam kuisioner dan setiap item pertanyaan diberi skor berdasarkan pendapat (James dan Dean, 1992) yaitu : tinggi (3), sedang (2), dan rendah (1), maksudnya bahwa setiap jawaban yang tersedia diberi skor yang berbeda. Pilihan jawaban yang paling positif yaitu jawaban A diberi skor tertinggi yaitu tiga. Sedangkan untuk pilihan B dan $C$ masing-masing diberi skor dua dan satu. Skor untuk masing-masing responden dijumlahkan untuk mengetahui partisipasi responden tersebut. Adapun rincian skor dapat dilihat pada Tabel 2.

Interval kelas indikator dibedakan menjadi tiga kelas, yaitu : Tinggi, Sedang, dan Rendah. Menurut Suparman (1990), interval kelas dapat ditentukan sebagai berikut:

$$
\mathrm{C}=(\mathrm{Xn}-\mathrm{Xi}) / \mathrm{K}=(2331-777) / 3=518
$$

Keterangan :

$\begin{array}{ll}\mathrm{C} & =\text { Interval kelas } \\ \mathrm{K} & =\text { Jumlah kelas } \\ \mathrm{Xn} & =\text { Skor maksimum } \\ \mathrm{Xi} & =\text { Skor minimum }\end{array}$

Tabel 2. Skor Penilaian Tingkat Pengetahuan Petani Padi Sawah Terhadap Pertanian Organik.

\begin{tabular}{clcc}
\hline \multirow{2}{*}{ No } & \multicolumn{1}{c}{ Indikator } & \multicolumn{2}{c}{ Skor } \\
\cline { 3 - 4 } & & Minimum & Maksimum \\
\hline 1. & Prinsip-prinsip Pertanian Organik & 111 & 333 \\
2. & Varietas Benih & 148 & 444 \\
3. & Pemupukan & 259 & 777 \\
4. & Pengendalian & 222 & 666 \\
5. & Keuntungan Pertanian Organik & 37 & 111 \\
\hline & Total Skor & $\mathbf{7 7 7}$ & $\mathbf{2 3 3 1}$ \\
\hline
\end{tabular}

Hasil perhitungan di atas dapat digunakan untuk membuat daftar distribusi indikator yang masing-masing disajikan dalam tabel dibawah ini. 
Tabel 3. Interval Kelas Tingkat Pengetahuan Petani Padi Sawah Terhadap Pertanian Organik

\begin{tabular}{ccc}
\hline No & Interval Nilai & Tingkat Pengetahuan Petani \\
\hline 1. & $777-1295$ & Rendah \\
2. & $1295,01-1813,01$ & Sedang \\
3. & $1813,02-2331,00$ & Tinggi \\
\hline
\end{tabular}

Selanjutnya data hasil lapangan diolah, ditabulasi dan diinterprestasikan secara deskriptif.

\section{Hasil dan Pembahasan}

Letak Administratif Desa Manunggal Jaya merupakan satu di antara 13 desa yang berada di Kecamatan Tenggarong Seberang Kabupaten Kutai Kartanegara. Jarak dari pusat Kota 15 km, jarak dari lbu Kota Kabupaten 15 km dan jarak dari lbu Kota Provinsi $15 \mathrm{~km}$. Luas wilayah Desa Manunggal Jaya secara keseluruhan yaitu 16,350 km2.

Penanaman padi sawah di Desa Manunggal Jaya dilakukan dua kali musim tanam dalam setahun. Musim tanam pertama berlangsung pada bulan Oktober sampai Februari, dan musim tanam kedua berlangsung pada bulan April hingga Agustus. Berdasarkan hasil wawancara terhadap petani, sebagian besar petani menyatakan mereka melakukan pengairan sesuai dengan kebutuhan tanaman, dan melakukan kegiatan pengairan sesuai dengan ketersediaan air. Selain itu, tujuan melakukan pengairan untuk menekan pertumbuhan gulma, dan menekan serangan hama (tikus).

Kegiatan pengamatan tanaman dilakukan untuk mengetahui permasalahan yang ada pada tanaman padi sawah, dan lahan sawah seperti adanya serangan hama dan penyakit, keadaan air, dan pertumbuhan tanaman. Kegiatan ini biasanya dilakukan petani seminggu sekali, namun bagi petani yang memiliki sawah di sekitar rumah lebih rutin melakukan pengamatan.

Kegiatan penyulaman pada tanaman padi dilakukan untuk mengganti tanaman padi yang rusak. Biasanya petani melakukan penyulaman paling lambat 7 HST (hari setelah tanam) karena jika dilakukan lebih dari 7 HST makan akan terjadi persaingan perebutan nutrisi makanan antara tanaman yang baru ditanam dan tanaman yang telah tumbuh.

Kegiatan penyiangan dan sanitasi lingkungan dilakukan untuk membebaskan tanaman padi sawah dari gangguan gulma atau tumbuhan lainnya yang ada di sekitar tanaman padi yang dapat merugikan. Penyiangan dilakukan dengan cara membersihkan tanaman liar (gulma) yang ada di sekitar dan membersihkan area pematang dari sampah, namun kegiatan ini tidak sepenuhnya dilakukan petani, kenyataannya di area persawahan masih terlihat beberapa botol bekas pestisida kimia dan sampah lainnya yang terlihat dan tidak dikumpulkan.

Petani di Desa Manunggal Jaya kurang memperhatikan prinsip-prinsip pertanian organik dimana petani cenderung menggunakan pupuk kimia dan pestisdia kimia dalam 
kegiatan usaha taninya dan kemudian membuang botol bekas di sekitar lahan pertanian tanpa memperhatikan kesehatan tanah, tanaman, hewan dan manusia yang ada di sekitar. Selain itu, kebiasan petani membakar jerami di sekitar lahan sawah dapat menyebabkan mikroorganisme, udara dan tanah menjadi rusak.

Petani di Desa Manunggal Jaya menggunakan varietas yang berbeda, sebagian petani menggunakan varietas Ciherang, Cimelati, IR 64, dan Sintanur. Adanya perbedaan varietas ini disebabkan oleh keterlambatan varietas benih dari instansi atau dinas/PPL setempat. Selain itu, ada beberapa petani menggunakan kembali benih turunan dari benih sebelumnya, hal ini disebabkan tidak tersedianya benih varietas yang baru, kemudian petani telah melihat hasil dari varietas benih yang telah digunakan cukup baik sehingga petani hanya menggunakan benih yang ada tanpa mengeluarkan banyak biaya.

Petani di Desa Manunggal Jaya sebagian besar menggunakan pupuk kimia dalam kegiatan pemupukan, hal ini didasari oleh kebiasan-kebiasan petani secara turun temurun yang memilih menggunakan yang lebih praktis, mudah didapatkan, mudah dalam pengaplikasian, hasil lebih cepat terlihat, dan tidak memerlukan banyak pupuk seperti pupuk organik. Meski demikian, ada beberapa petani juga yang menggunakan pupuk organik dalam kegiatan pemupukan yang ia lakukan, namun hal ini tidak menyeluruh dilakukan karena bagi petani untuk menerapkan sistem pertanian secara menyeluruh sangat sulit dilakukan.

Dalam kegiatan pengendalian OPT, petani di Desa Manunggal Jaya cenderung menggunakan pestisida kimia dan menggunakan cara yang mekanis untuk mengusir hama, contohnya pada tikus, petani biasanya membasmi tikus dengan cara mengisi air sampai penuh di lubang tempat persembunyian tikus yang ada di sekitar lahan sawah, kemudian setelah tikus keluar dari lubang, petani akan menangkap tikus dengan menggunakan jaring. Selain itu, untuk pengendalian hama burung, petani menggunakan orang-orangan sawah sehingga burung menjadi takut untuk mendekat. Meski demikian, ada beberapa petani yang melakukan pengendalian OPT dengan menggunakan pestisida nabati.

Petani di Desa Manunggal Jaya sebagian besar menggunakan sistem pertanian konvensional, namun ada beberapa petani yang mulai menerapkan pertanian organik meski tidak sepenuhnya. Petani yang menerapkan pertanian organik mengatakan bahwa ia merasa puas dengan hasil yang ia peroleh meskipun tidak menutupi hasil secara ekonomis, tetapi hasil dari segi prinsip-prinsip pertanian organik yaitu kesehatan, ekologi, keadilan, dan perlindungan ia merasa cukup puas karena bisa menghasilkan makanan yang aman dan sehat bagi keluarga dan orang lain. 


\subsection{Karakteristik Responden}

Berdasarkan hasil wawancara dan pengamatan langsung yang dilakukan terhadap 37 responden petani padi sawah di Desa Manunggal Jaya Kecamatan Tenggarong Seberang, maka diperoleh gambaran umum karakteristik responden sebagai berikut:

Tabel 4. Profil Responden Penelitian Tingkat Pengetahuan Petani Padi Sawah

\begin{tabular}{lllll}
\hline No. & Pengelompokan Berdasarkan & Jumlah & Persentase (\%) \\
\hline 1. & Tingkat Umur & Produktif (15-64) & 35 & 94.59 \\
& & Lanjut (>64) & 2 & 5.41 \\
2. & \multirow{3}{*}{ Pendidikan } & Jumlah & $\mathbf{3 7}$ & $\mathbf{1 0 0}$ \\
& & SD & 28 & 75.68 \\
& SMP & 5 & 13.51 \\
3. & SMA & 4 & 10.81 \\
& \multirow{2}{*}{ Luas Lahan } & Jumlah & $\mathbf{3 7}$ & $\mathbf{1 0 0}$ \\
& & $0,5-1,0$ & 28 & 75.68 \\
& $1,5-2,0$ & 5 & 13.51 \\
& $2,5-3,0$ & 2 & 5.41 \\
& $3,5-4,0$ & 2 & 5.41 \\
\hline
\end{tabular}

\subsection{Tingkat Pengetahuan Petani Padi Sawah Terhadap Pertanian Organik}

Pengetahuan merupakan salah satu komponen perilaku petani yang turut menjadi faktor dalam adopsi inovasi. Tingkat pengetahuan petani mempengaruhi petani dalam mengadopsi teknologi baru dan keutuhan usaha taninya. Selanjutnya, dijelaskan bahwa dalam mengadopsi pembaharuan atau perubahan, petani memerlukan pengetahuan mengenai aspek teoritis dan pengetahuan praktis.

Berdasarkan hasil observasi yang dilakukan kurang lebih selama dua bulan dan hasil perhitungan dari kuesioner yang telah ditetapkan dan diukur menggunakan skala likert didapatkan hasil tingkat pengetahuan petani padi sawah terhadap pertanian organik, dapat dilihat pada Tabel 5.

Tabel 5. Tingkat Pengetahuan Petani Padi Sawah Terhadap Pertanian Organik

\begin{tabular}{|c|c|c|c|c|c|c|c|c|c|}
\hline \multirow[t]{2}{*}{ No } & \multirow[t]{2}{*}{ Indikator } & \multicolumn{4}{|c|}{ Kelas Pemula } & \multicolumn{4}{|c|}{ Kelas Lanjut } \\
\hline & & $\begin{array}{c}\text { Jumlah } \\
\text { Responden }\end{array}$ & $\begin{array}{c}\text { Persentase } \\
(\%)\end{array}$ & $\begin{array}{l}\text { Skor } \\
\text { Total }\end{array}$ & Kategori & $\begin{array}{c}\text { Jumlah } \\
\text { Responden }\end{array}$ & $\begin{array}{c}\text { Persentase } \\
(\%)\end{array}$ & $\begin{array}{l}\text { Skor } \\
\text { Total }\end{array}$ & Kategori \\
\hline 1. & $\begin{array}{l}\text { Prinsip-prinsip } \\
\text { Pertanian } \\
\text { Organik }\end{array}$ & 13 & 100 & 108 & Tinggi & 24 & 100 & 199 & Tinggi \\
\hline 2. & Varietas Benih & 13 & 100 & 144 & Tinggi & 24 & 100 & 271 & Tinggi \\
\hline 3. & Pemupukan & 13 & 100 & 192 & Sedang & 24 & 100 & 446 & Tinggi \\
\hline 4. & $\begin{array}{l}\text { Pengendalian } \\
\text { OPT }\end{array}$ & 13 & 100 & 163 & Sedang & 24 & 100 & 376 & Tinggi \\
\hline & Jumlah Skor & & & 639 & & & & 1357 & \\
\hline
\end{tabular}

Berdasarkan Tabel 5, dapat diketahui bahwa tingkat pengetahuan petani padi sawah terhadap pertanian organik di Desa Manunggal Jaya termasuk dalam kategori tinggi dengan jumlah skor 639 untuk kelompok tani kelas pemula, dimana dari 5 indikator, 2 indikator memiliki kategori sedang, dan pada kelas lanjut memiliki skor 1357, dimana dari 5 indikator memiliki kategori tingkat pengetahuan yang tinggi. Secara umum tingkat pengetahuan petani terhadap pertanian organik di Desa Manunggal Jaya termasuk dalam 
kategori "tinggi" namun, bukan berarti semua petani responden memiliki tingkat pengetahuan yang tinggi terhadap pertanian organik.

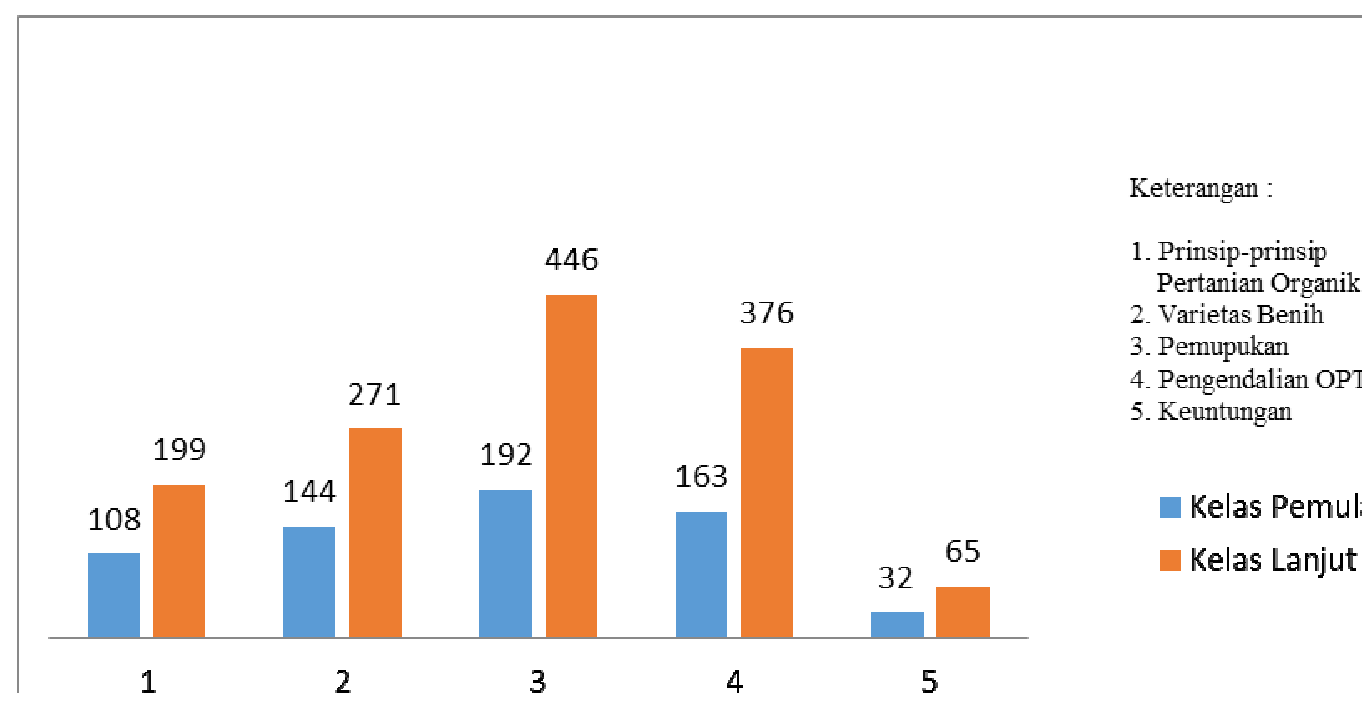

Gambar 1.Tingkat Pengetahuan Petani Padi Sawah Terhadap Pertanian Organik

Berdasarkan Gambar 1, dapat diketahui bahwa tingkat pengetahuan petani padi sawah terhadap pertanian organik di Desa Manunggal Jaya termasuk dalam kategori tinggi dengan jumlah skor 108 untuk kelompok tani kelas pemula dan skor 199 pada kelas lanjut pada indikator prinsip-prinsip pertanian organik. Pada indikator varietas benih, kelompok tani kelas pemula memiliki skor 144 sedangkan pada kelas lanjut memiliki skor 271. Pada indikator pemupukan, kelompok tani kelas pemula memiliki skor 192 sedangkan pada kelas lanjut memiliki skor 446. Pada indikator pengendalian OPT, kelompok tani kelas pemula memiliki skor 163 sedangkan pada kelas lanjut memiliki skor 376. Pada indikator keuntungan pertanian organik, kelompok tani kelas pemula memiliki skor 32 sedangkan pada kelas lanjut memiliki skor 65 . Berikut hasil penelitian tingkat pengetahuan petani padi sawah terhadap pertanian organik di Desa Manunggal Jaya.

\section{Prinsip-prinsip Pertanian Organik}

Berdasarkan hasil penelitian yang telah dilakukan, rincian dari tingkat pengetahuan petani dalam indikator prinsip-prinsip pertanian organik dapat dilihat pada Tabel 6.

Tabel 6. Tingkat Pengetahuan Petani Padi Sawah Terhadap Pertanian Organik dalam kategori Prinsip-prinsip Pertanian Organik

\begin{tabular}{llcccc}
\hline No & Kategori & \multicolumn{2}{c}{ Kelas Pemula } & Kelas Lanjut \\
\cline { 3 - 6 } & & $\begin{array}{c}\text { Jumlah } \\
\text { Responden }\end{array}$ & $\begin{array}{c}\text { Persentase } \\
(\%)\end{array}$ & $\begin{array}{c}\text { Jumlah } \\
\text { Responden }\end{array}$ & $\begin{array}{c}\text { Persentase } \\
(\%)\end{array}$ \\
\hline 1. & 0 & 0 & 0 & 0 \\
2. & Rendah & 3 & 23.08 & 5 & 20.83 \\
3. & Sedang & 10 & 76.92 & 19 & 79.17 \\
\hline \multicolumn{2}{l}{} & Jumlah & 13 & 100 & 24 \\
\hline
\end{tabular}




\section{Varietas Benih}

Berdasarkan hasil penelitian yang telah dilakukan, rincian dari tingkat pengetahuan petani dalam indikator Varietas Benih dapat dilihat pada Tabel 7.

Tabel 7. Tingkat Pengetahuan Petani Padi Sawah Terhadap Pertanian Organik dalam kategori Varietas Benih Pertanian Organik.

\begin{tabular}{lccccc}
\hline No & Kategori & \multicolumn{2}{c}{ Kelas Pemula } & Kelas Lanjut \\
\cline { 3 - 6 } & & $\begin{array}{c}\text { Jumlah } \\
\text { Responden }\end{array}$ & $\begin{array}{c}\text { Persentase } \\
(\%)\end{array}$ & $\begin{array}{c}\text { Jumlah } \\
\text { Responden }\end{array}$ & $\begin{array}{c}\text { Persentase } \\
(\%)\end{array}$ \\
\hline 1. & 0 & 0 & 0 & 0 \\
2. & Rendah & 3 & 23.08 & 4 & 16.67 \\
3. & Sedang & 10 & 76.92 & 20 & 83.33 \\
\hline \multicolumn{7}{r}{} & Jumlah & 13 & 100 & 24 \\
\hline & Jumlah Skor $=415$ & Rata-rata $=11.12$ \\
\hline & Kategori & Tinggi \\
\hline
\end{tabular}

\section{Pemupukan}

Berdasarkan hasil penelitian yang telah dilakukan, rincian dari tingkat pengetahuan petani dalam indikator pemupukan dapat dilihat pada Tabel 8.

Tabel 8. Tingkat Pengetahuan Petani Padi Sawah Terhadap Pertanian Organik dalam kategori Pemupukan.

\begin{tabular}{|c|c|c|c|c|c|}
\hline \multirow[t]{2}{*}{ No } & \multirow[t]{2}{*}{ Kategori } & \multicolumn{2}{|c|}{ Kelas Pemula } & \multicolumn{2}{|l|}{ Kelas Lanjut } \\
\hline & & $\begin{array}{c}\text { Jumlah } \\
\text { Responden }\end{array}$ & $\begin{array}{c}\text { Persentase } \\
(\%)\end{array}$ & $\begin{array}{c}\text { Jumlah } \\
\text { Responden }\end{array}$ & $\begin{array}{c}\text { Persentase } \\
(\%)\end{array}$ \\
\hline 1. & Rendah & 0 & 0 & 1 & 4.17 \\
\hline 2. & Sedang & 11 & 84.62 & 7 & 29.17 \\
\hline 3. & Tinggi & 2 & 15.38 & 16 & 66.67 \\
\hline \multicolumn{2}{|r|}{ Jumlah } & 13 & 100 & 24 & 100 \\
\hline \multicolumn{2}{|r|}{ Jumlah Skor $=638$} & \multicolumn{3}{|c|}{ Rata-rata $=17.24$} & \\
\hline \multicolumn{2}{|r|}{ Kategori } & & Tinggi & & \\
\hline
\end{tabular}

\section{Pengendalian Organisme Pengganggu Tanaman (OPT)}

Berdasarkan hasil penelitian yang telah dilakukan, rincian dari tingkat pengetahuan petani dalam indikator pengendalian OPT dapat dilihat pada Tabel 9.

Tabel 9. Tingkat Pengetahuan Petani Padi Sawah Terhadap Pertanian Organik dalam kategori Pengendalian OPT

\begin{tabular}{|c|c|c|c|c|c|}
\hline \multirow[t]{2}{*}{ No } & \multirow[t]{2}{*}{ Kategori } & \multicolumn{2}{|c|}{ Kelas Pemula } & \multicolumn{2}{|l|}{ Kelas Lanjut } \\
\hline & & $\begin{array}{c}\text { Jumlah } \\
\text { Responden }\end{array}$ & $\begin{array}{c}\text { Persentase } \\
(\%)\end{array}$ & $\begin{array}{c}\text { Jumlah } \\
\text { Responden } \\
\end{array}$ & $\begin{array}{c}\text { Persentase } \\
(\%)\end{array}$ \\
\hline 1. & Rendah & 0 & 0 & 1 & 4.17 \\
\hline 2. & Sedang & 12 & 92.31 & 7 & 29.17 \\
\hline 3. & Tinggi & 1 & 7.69 & 16 & 66.67 \\
\hline \multicolumn{2}{|r|}{ Jumlah } & 13 & 100 & 24 & 100 \\
\hline \multicolumn{2}{|r|}{ Jumlah Skor $=539$} & \multicolumn{3}{|c|}{ Rata-rata $=14.57$} & \\
\hline \multicolumn{2}{|r|}{ Kategori } & & Tinggi & & \\
\hline
\end{tabular}

\section{Keuntungan Pertanian Organik}

Berdasarkan hasil penelitian yang telah dilakukan, rincian dari tingkat pengetahuan petani dalam indikator keunggulan pertanian organik dapat dilihat pada Tabel 10. 
Tabel 10. Tingkat Pengetahuan Petani Padi Sawah Terhadap Pertanian Organik dalam kategori Keuntungan Pertanian Organik

\begin{tabular}{lccccc}
\hline No & Kategori & \multicolumn{2}{c}{ Kelas Pemula } & \multicolumn{2}{c}{ Kelas Lanjut } \\
\cline { 3 - 6 } & & $\begin{array}{c}\text { Jumlah } \\
\text { Responden }\end{array}$ & $\begin{array}{c}\text { Persentase } \\
(\%)\end{array}$ & $\begin{array}{c}\text { Jumlah } \\
\text { Responden }\end{array}$ & $\begin{array}{c}\text { Persentase } \\
(\%)\end{array}$ \\
\hline 1. & Rendah & 0 & 0 & 0 & 0 \\
2. & Sedang & 7 & 53.85 & 7 & 29.19 \\
3. & Tinggi & 13 & 46.15 & 17 & 70.83 \\
\hline \multicolumn{7}{r}{} & Jumlah & 100 & 24 & 100 \\
\hline & Jumlah Skor $=97$ & Rata-rata $=2.62$ \\
\hline
\end{tabular}

\subsection{Pembahasan}

Pengetahuan merupakan satu diantara komponen perilaku petani yang turut menjadi faktor dalam adopsi inovasi. Tingkat pengetahuan petani mempengaruhi petani dalam mengadopsi teknologi baru dan keutuhan usaha taninya. Selanjutnya, dijelaskan bahwa dalam mengadopsi pembaharuan atau perubahan, petani memerlukan pengetahuan mengenai aspek teoritis dan pengetahuan praktis.

Berdasarkan hasil penelitian yang telah dilakukan, untuk mengukur tingkat pengetahuan petani padi sawah terhadap pertanian organik terdapat 3 kategori yaitu rendah, sedang dan tinggi. Berikut penjelasannya berdasarkan hasil penelitian tingkat pengetahuan petani padi sawah terhadap pertanian organik di Desa Manunggal Jaya.

Berdasarkan Tabel 6, dapat diketahui bahwa tingkat pengetahuan petani padi sawah pada kategori prinsip-prinsip pertanian organik di Desa Manunggal Jaya termasuk dalam kategori "tinggi" dengan jumlah skor 307 dan skor rata-rata 8,30.

Tingginya tingkat pengetahuan petani padi sawah terhadap pertanian organik pada kategori prinsip-prinsip pertanian organik ini karena petani telah mendapatkan sosialisasi atau kegiatan penyuluhan tentang pertanian organik khususnya tentang prinspprinsip pertanian organik yang mana prinsip-prinsip ini lebih mengutamakan kesehatan lingkungan, ekologi, keadilan dan perlindungan. Selain itu, petani mengetahui bahwa produk-produk dari pertanian organik juga aman dan sehat. Meski demikian, dalam tahap penerapan pertanian organik, petani belum melakukannya, hal ini dikarenakan pertanian organik tidak meningkatkan hasil persatuan luas, bahkan cenderung menurun dari waktu ke waktu apabila aplikasinya tidak tepat. Petani menganggap bahwa pertanian organik hanya cocok untuk diterapkan pada komoditas-komoditas tertentu saja yang memiliki nilai ekonomis sangat tinggi dan banyak dikonsumsi oleh masyarakat kalangan atas seperti sayur-sayuran dan buah-buahan. Selain itu, fakta yang penulis temukan di lapangan menunjukkan bahwa harga jual beras organik dan beras konvensional memiliki harga yang cenderung sama, padahal untuk lahan seluas 1 ha jika petani bercocok tanam dengan sistem pertanian organik, maka ia akan membutuhkan banyak jerami dan pupuk 
kandang. Selain itu, harga pestisida organik serta uji efeksifitas dan efisiensi aplikasi pestisida organik cenderung mahal.

Berdasarkan hasil wawancara dengan petani, 21,62\% petani memiliki tingkat pengetahuan yang "sedang' dalam kategori prinsip-prinsip pertanian organik. Petani memiliki tingkat pengetahuan yang sedang adalah petani yang kurang aktif dalam kegiatan kelompok tani sehingga kurang mendapatkan informasi tentang adanya kegiatan sosialisasi atau penyuluhan. Petani yang memiliki tingkat pengetahuan yang sedang cenderung aktif hanya dalam kegiatan usaha taninya sendiri tanpa mengetahui perkembangan-perkembangan terbaru mengenai pertanian secara umum, mereka hanya mengetahui informasi dari beberapa kerabat petani lainnya sehingga tingkat pengetahuan petani dalam kategori prinsip-prinsip pertanian organik dari 100\% petani, $21,62 \%$ memiliki tingkat pengetahuan yang "sedang".

Berdasarkan Tabel 7, dapat diketahui bahwa tingkat pengetahuan petani padi sawah pada kategori Varietas Benih di Desa Manunggal Jaya termasuk dalam kategori "tinggi" dengan jumlah skor 415 dan skor rata-rata 11,12.

Berdasarkan hasil wawancara dengan petani, $81,08 \%$ petani mengetahui jenis varietas benih yang unggul. Petani mengetahui bahwa penggunaan varietas benih yang unggul merupakan kunci awal dari keberhasilan budidaya. Untuk informasi, petani cenderung mencari informasi tambahan mengenai benih yang baik atau unggul dari kerabat tani yang lain, petani juga mengikuti saran dari penyuluh tentang penggunaan benih unggul terbaru. Meski ketersediaan benih dari instansi terkait terlambat, tidak menghalangi petani untuk menggunakan benih unggul, petani mencari benih unggul hingga keluar daerah. Petani melakukan hal ini karena petani mengetahui betapa pentingnya benih dalam kegiatan budidaya, dengan benih yang unggul dan penanganan yang baik petani yakin bahwa hasil produksinya juga akan memuaskan.

Berdasarkan hasil wawancara terhadap 37 responden, sebagian besar petani menggunakan benih dengan varietas IR 64, Sintanur, Inpari Sidenuk, Cimelati, dan Ciherang. Meski demikian, ada beberapa petani menggunakan benih turunan dari yang sebelumnya. Hal ini terjadi karena benih yang dari dinas PPL setempat terlambat datang sehingga petani menggunakan benih yang diperoleh dari hasil panen musim lalu yang telah terseleksi kemudian dijadikan benih lagi atau dari tetangga yang juga memiliki hasil panen yang baik untuk dijadikan benih. Untuk harga benih yang diperoleh dari tetangga biasanya memiliki harga antara Rp.9.000,-/kg hingga Rp. 10.000,- atau dengan sistem tukar gabah dengan benih yang akan digunakan petani.

Berdasarkan hasil wawancara dengan petani, 18,92\% petani memiliki tingkat pengetahuan yang "sedang" dalam kategori varietas benih. Petani yang memiliki tingkat pengetahun yang sedang adalah petani yang kurang aktif dalam kegiatan kelompok tani 
sehingga kurang mendapatkan informasi tentang pertanian secara umum dan mengakibatkan pengetahuan petani menjadi terbatas tentang pertanian khususnya pada varietas benih. Selain itu, petani yang memiliki tingkat pengetahuan yang sedang adalah petani yang memiliki usia sekitar 30 tahun yang mana petani-petani ini memiliki pengalaman berusaha tani yang masih terbilang muda meskipun mereka masuk dalam kelompok tani kelas lanjut.

Berdasarkan Tabel 8, dapat diketahui bahwa tingkat pengetahuan petani padi sawah pada kategori Pemupukan di Desa Manunggal Jaya termasuk dalam kategori "tinggi" dengan jumlah skor 638 dan skor rata-rata 17,24.

Berdasarkan hasil wawancara dengan petani, 48,65\% petani mengetahui tentang pupuk organik, mulai dari bahan-bahan yang digunakan untuk membuat pupuk organik, hingga keunggulan dan kelemahan dari pupuk organik. Berdasarkan fakta yang ada dilapangan, ada beberapa petani yang melakukan uji coba pertanian organik, mereka secara bersama mulai menerapkan sistem pertanian berbasis organik. Petani-petani ini mulai melakukan kegiatan pemupukan dengan menggunakan pupuk organik namun untuk pengendalian hama mereka cenderung masih menggunakan pestisida kimia.

Adapun jenis pupuk organik yang biasa digunakan oleh petani di Desa Manunggal Jaya adalah pupuk organik Agrodyke dan pupuk organik dari kotoran hewan yang diperoleh dari ketua kelompok tani Pringgondani (Bapak Bariman) dan kelompok tani yang ada di desa lain. Selain itu, ada beberapa petani lainnya seperti anggota kelompok tani Sumber Rejeki (Bapak Karyadi) membuat pupuk organik sendiri tanpa harus membeli dengan memanfaatkan beberapa tanaman dan kotoran hewan yang ada disekitar. Untuk membuat pupuk organik, bahan-bahan yang dibutuhkan cenderung mudah ditemukan seperti kotoran hewan karena sebagian besar petani di Desa Manunggal Jaya memiliki hewan ternak seperti sapi dan kambing.

Berdasarkan hasil wawancara dengan beberapa petani yang mulai mengambil tahap penerapan pertanian organik ini diketahui bahwa alasan mereka untuk mulai menerapkan sistem pertanian organik karena mereka ingin mengetahui perbedaan hasil dari pertanian organik dan pertanian konvensional baik dari hasil produksi maupun dari segi ekonomis.

Berdasarkan hasil wawancara dengan petani, 48,65\% petani memiliki tingkat pengetahuan yang "sedang" dalam kategori pemupukan. Petani yang memiliki tingkat pengetahuan yang sedang adalah petani yang menganggap bahwa pemupukan menggunakan sistem organik bukan merupakan kebutuhan utama mereka sehingga untuk mencari informasi tentang pemupukan secara organik dan membuat pupuk organik sendiri petani cenderung mengabaikannya karena mereka menganggap bahwa itu bukan merupakan kebutuhan utama mereka. Resiko akan kegagalan dari sistem pertanian 
organik membuat petani kurang memiliki minat dalam mencari informasi tambahan tentang pemupukan secara organik.

Pengetahuan petani tentang prinsip-prinsip pertanian organik, varietas benih, dan keunggulan pertanian organik cukup tinggi, karena petani-petani ini sering mengikuti kegiatan sosialisasi tentang pertanian organik, akan tetapi dalam hal pemupukan masih banyak petani yang memiliki tingkat pengetahuan yang "sedang" bahkan cenderung "rendah" karena petani mengganggap bahwa pemupukan secara organik bukanlah solusi utama bagi kegiatan usaha tani mereka, sehingga petani tidak ingin belajar bagaimana cara membuat pupuk organik sendiri dan cenderung menggunakan cara yang lebih mudah dan hasilnya cepat terlihat yaitu dengan menggunakan pupuk-pupuk kimia seperti Pupuk Urea, Pupuk SP36, Pupuk Phonsca, Pupuk KCL, dan Pupuk Kanada. Selain itu, alasan petani untuk tidak beminat belajar tentang pembuatan pupuk organik dan menerapkan dalam kegiatan usaha tani mereka adalah karena petani tidak memiliki banyak waktu untuk membuatnya. Sebagian besar petani di Desa Manunggal Jaya memiliki pekerjaan sampingan lainnya, sehingga ketika tanaman padi masuk dalam fase pemeliharaan dan pemupukan petani cenderung mencari pekerjaan atau kesibukan lainnya seperti mencari makanan atau rumput untuk hewan-hewan ternak mereka sehingga petani tidak memiliki banyak waktu untuk membuat pupuk-pupuk organik dan menerapkannya dalam kegiatan usaha tani mereka.

Berdasarkan Tabel 9, dapat diketahui bahwa tingkat pengetahuan petani padi sawah pada kategori Pengendalian OPT di Desa Manunggal Jaya termasuk dalam kategori "tinggi" dengan jumlah skor 539 dan skor rata-rata 14,57

Berdasarkan hasil wawancara dengan petani, 45,95\% petani memiliki tingkat pengetahuan yang "tinggi" dalam kategori pengendalian OPT. Petani yang memiliki tingkat pengetahuan yang tinggi adalah petani yang sudah masuk ke tahap penerapan sistem pertanian semi organik, mereka mengetahui semua informasi tentang pertanian organik bahkan dalam proses pembuatan pestisida nabati mereka mengetahui dan menerapkannya dalam sistem budidaya tanaman sayuran mereka, tetapi dalam kegiatan budidaya tanaman padi, mereka cenderung menggunakan pestisida kimia karena takut dengan resiko yang akan terjadi. Salah satu hama yang sangat membuat petani resah adalah hama tikus, oleh sebab itu petani tidak berani mengambil langkah untuk mengatasinya dengan menggunakan pestisida nabati karena petani menyadari bahwa pestisida nabati tidak mampu untuk membunuh hama yang menyerang padi sawah mereka.

Adapun jenis pestisida kimia yang biasa digunakan oleh petani di Desa Manunggal Jaya adalah Herbisida Bitop, Herbisida Gramoxone, Herbisida Round Up, Herbisida Gempur dan Ruso yang digunakan petani untuk mengendalikan gulma atau 
tanaman pengganggu lainnya serta Klerat RM-B yang digunakan petani untuk membasmi hama tikus. Meski demikian, ada anggota kelompok tani di Sumber Rejeki (Bapak Karyadi) yang tetap menggunakan pestisida nabati untuk mengendalikan hama dan penyakit yang mengganggu tanamannya sehingga perbedaan tampilan tanaman padi yang menggunakan pestisida nabati dengan tanaman padi yang menggunakan pestisida kimia memiliki perbedaan yang cukup mencolok yaitu helai daun padi yang menggunakan pestisida nabati memiliki warna yang kuning di pangkal daun karena terserang oleh hama dan penyakit serta memiliki warna hijau yang sedikit muda atau pudar sedangkan tanaman padi yang menggunakan pestisida kimia atau yang mendapat perlakuan secara kimia sejak awal tanam memiliki warna hijau tua yang cerah. Untuk membuat pestisida nabati, bahan-bahan dan tanaman yang digunakan atau yang dibutuhkan termasuk mudah ditemukan disekitar karena beberapa petani sengaja menanam karena mereka menyadari bahwa tanaman-tanaman tersebut sangat bermanfaat bagi kegiatan usaha tani mereka. Adapun bahan-bahan atau tanaman yang ditanam oleh petani antara lain adalah daun sirsak, daun papaya, dan gadung.

Berdasarkan hasil wawancara dengan petani, 51,35\% petani memiliki tingkat pengetahuan yang "sedang" dalam kategori pengendalian OPT. Petani yang memiliki tingkat pengetahuan yang sedang adalah petani yang menganggap bahwa pengendalian OPT menggunakan sistem organik bukan merupakan kebutuhan utama mereka sehingga untuk mencari informasi tentang pengendalian OPT secara organik dan membuat pestisida nabati sendiri petani cenderung mengabaikannya karena mereka menganggap bahwa itu bukan merupakan kebutuhan utama mereka. Resiko akan kegagalan dari sistem pertanian organik membuat petani kurang memiliki minat dalam mencari informasi tambahan tentang pengendalian OPT secara organik. Selain itu, alasan petani untuk tidak beminat belajar tentang pembuatan pestisida kimia dan menerapkan dalam kegiatan usaha tani mereka adalah karena petani tidak memiliki banyak waktu untuk membuatnya. Sebagian besar petani di Desa Manunggal Jaya memiliki pekerjaan sampingan lainnya, sehingga ketika tanaman padi masuk dalam fase pemeliharaan dan pemupukan petani cenderung mencari pekerjaan atau kesibukan lainnya seperti mencari makanan atau rumput untuk hewan-hewan ternak mereka sehingga petani tidak memiliki banyak waktu untuk membuat pupuk-pupuk organik dan menerapkannya dalam kegiatan usaha tani mereka.

Berdasarkan Tabel 10, dapat diketahui bahwa tingkat pengetahuan petani padi sawah pada kategori Keunggulan Pertanian Organik di Desa Manunggal Jaya termasuk dalam kategori "tinggi" dengan jumlah skor 97 dan skor rata-rata 2,62

Berdasarkan hasil wawancara dengan petani, 62,16\% petani mengetahui tentang keuntungan pertanian organik. Petani yang memiliki tingkat pengetahuan yang tinggi 
adalah petani yang telah menerapkan sistem pertanian organik, mereka menyadari bahwa pertanian organik memberikan banyak keuntungan bagi manusia bahkan bagi lingkungan sekitar mereka.

Berdasarkan hasil wawancara dengan petani, 37,84\% petani memiliki pengetahuan yang "sedang" dalam kategori keunggulan pertanian organik. Petani yang memiliki tingkat pengetahuan yang sedang adalah petani yang kurang aktif dalam kegiatan kelompok tani sehingga kurang mendapat informasi tentang pertanian organik. Selain itu, tidak adanya minat dalam penerapan pertanian organik membuat petani cenderung mengabaikan informasi mengenai pertanian organik dan memfokuskan diri mereka dalam kegiatan usaha tani mereka dengan menggunakan cara yang yang konvensional.

Berdasarkan hasil wawancara dengan 37 petani, ada beberapa kendala dan hambatan yang menyebabkan petani kurang berminat dalam menerapkan sistem pertanian organik dalam kegiatan usaha tani mereka, antara lain ;

1. Luas lahan yang menerapkan pertanian organik relatif kecil dan terletak di sekitar lahan budidaya pertanian non organik sehingga membuat lahan pertanian organik lebih rawan terhadap hama dan penyakit.

2. Sumber air yang ada sudah tercemar pupuk, pestisida, dan bahan kimia lainnya yang dapat merusak lingkungan sekitar lahan pertanian organik.

3. Serangan hama dan penyakit tanaman yang semakin tinggi dan tidak bisa diatasi hanya dengan menggunakan cara yang organik karena petani menyadari bahwa pertanian organik hanya mampu mengusir hama tanpa bisa membunuhnya sedangkan pertanian non organik atau pengendalian secara kimia dapat membasmi dan membunuh hama yang menyerang tanaman mereka.

4. Pertanian organik dipandang sebagai pertanian yang merepotkan karena petani sudah terbiasa menggunakan pupuk dan pestisida kimia bahkan petani beranggapan tanpa pupuk kimia dan pestisida kimia usaha tani mereka tidak akan berhasil. Petani tidak ingin repot dan menginginkan sesuatu yang mudah dan cepat.

5. Hasil produksi pertanian konvensional cenderung lebih tinggi yaitu mencapai 1 ton untuk luas lahan 1 ha, sedangkan untuk pertanian organik masih belum diketahuai hasilnya karena petani masih melakukan uji coba pada musim tanam ini.

\section{Kesimpulan dan Saran}

Berdasarkan hasil penelitian dan pembahasan dapat ditarik kesimpulan bahwa Tingkat Pengetahuan Petani Padi Sawah Terhadap Pertanian Organik di Desa Manunggal Jaya diperoleh hasil dengan kategori "tinggi" baik pada kelompok tani kelas pemula maupun pada kelompok tani kelas lanjut. Tingkat Pengetahuan Petani Padi Sawah Terhadap Pertanian Organik di Desa Manunggal Jaya memiliki lima (5) indikator 
yaitu prinsip-prinsip pertanian organik, varietas benih, pemupukan, pengendalian OPT, dan keunggulan pertanian organik. Pada indikator pemupukan dan pengendalian OPT masuk dalam kategori "sedang" untuk kelas pemula, sedangkan pada indikator lainnya masuk dalam kategori "tinggi".

Saran yang dapat penulis berikan sehubungan dengan penelitian ini adalah :

1. Tingkat pengetahuan serta pemahaman petani tentang pertanian organik sangat baik karena petani telah mendapatkan sosialisasi dan penyuluhan tentang pertanian organik bahkan sebagian petani telah mengambil tahap penerapan semi organik, selanjutnya diharapkan agar pemahaman petani tentang pertanian organik terus dikembangkan sampai petani mengambil tahap penerapan organik secara penuh mulai dari pemupukan hingga pada pengendalian OPT.

2. Diharapkan agar kelompok tani kelas pemula dapat meningkatkan pengetahuan serta pemahaman pada indikator pemupukan dan pengendalian OPT dengan cara mengikuti kegiatan sosialisasi tentang pertanian organik khususnya pada pemupukan dan pengendalian OPT.

3. Diharapkan agar petani dapat mengurangi pemakaian pupuk kimia dan pestisida kimia sehingga dapat mengurangi kerusakan pada lingkungan dan pada kesehatan makhluk hidup.

\section{Daftar Pustaka}

Silalahi, Ulber. 2015. Metode Penelitian Sosial Kuantitatif. Refika Adiatma. Bandung.

Sutanto, R. 2000. Penerapan Pertanian Organik (Pemasyarakatan dan Pengembangannya). Kanisus. Yogyakarta.

Soetrisno, Loekman, 2002. Paradigma Baru Pertanian: Sebuah Tinjauan Sosiologis. Kanisius: Yogyakarta.

Winarno FG, 2004. Pengantar Pertanian Organik. M-Brio Press. Jakarta 